THURSDAY, APRIL 8, I920.

\section{The Universities and the Army.}

$\mathrm{M}^{2}$

ORE than a year ago-on February 20, I9I9-an article on "Education in the Army " was published in these columns in which urgent reasons were advanced for a new policy. During the intervening period, numerous contributions have been made to various newspapers and reviews on the same subject, and book has succeeded book animadverting on the educational defects of the Army organisation as revealed by the war. Great disappointment will be felt that these sincere representations have so far produced no more useful result than the Memorandum on the Army Estimates of I919-20, recently published by the War Office "in amplification of the speech of the Secretary of State in introducing the Estimates." That speech, delivered by Mr. Churchill on February 23, was able and serious within somewhat exiguous limits, but it contributed nothing to the question of educational reform in its military aspects. We are forced, therefore, to turn to the amplifying Memorandum in the anxious hope of finding the question discussed on broad lines and in a scientific spirit. It proves to be a Mother Hubbard cupboard containing only a schoolboy essay freely embellished with mixed metaphors. Thus :

"One of the important lessons of the war has been the extent to which the Army is dependent on the Universities. Great strides were made in this direction before the war, with the result that the Universities responded to the call for help in a splendid manner."

This belated recognition of the valuable work of the Universities in connection with the war is well and fair so far as it goes, but it affords no guarantee to the British public, whose ears are still attuned to the sad diapason of the war's tragedies, that the reorganisation of the Army on its educational side is to be taken seriously in hand. The fact that the Secretary of State, in his speech, found the subject unworthy of even a passing reference is surely disconcerting.

We pointed out recently that the Memorandum deserves to be commended for the proof it affords of the recognition by the Army of the importance of scientific research conducted both under its direct supervision and in our Universities and colleges. Every science and every scientific NO. 2632 , VOL. IO5] worker can make some contribution to national defence.

To give Mr. Churchill his due, he appears to realise the economy of men and money which may result from new applications of science. $\mathrm{He}$ quoted in his speech, as an example of the possibilities of the Air Force, the case of the recent Somaliland campaign, which, at a cost of $30,000 l$, achieved much more than an expedition before the war which cost 2,500,00ol.; and he described a new form of tank, which, so far from damaging the roads, actually improved them, and possessed an engine which, instead of overheating the interior, exercised a refrigerating effect. But what we ask, and what we shall insist on knowing, is whether this new spirit is to permeate the whole Army, or whether, when the wounds of war are healed and its bitter memories pass into subsonsciousness, the Army will revert to its old traditions.

Fortunately for the Army and for the nation, one of the root causes by which these traditions were fed has been effectively removed. Before the war, officers were not paid a living wage, and that system was deliberately perpetuated in order to maintain the tradition of the officer as a gentleman of means and leisure who did half a day's work for half a day's pay. As a writer in the New Statesman observed (January 25, I919) :

"It is no use pretending now that the system gave us an efficient Army. One does not gather grapes from thorns. The ablest boys in the country's schools went almost invariably into other callings. Some few officers, with the German menace before their eyes, did indeed work with most praiseworthy, unpaid energy in the years immediately preceding the war. But no gratitude to the 'Old Contemptibles' should blind us to the fact that, however devoted their officers were, they were clearly outclassed as professional men, both by their German opponents and by their French Allies; and that in spite of the unique opportunities afforded by Colonial and Indian war experience."

Under the revised rates of pay of Army officers, a junior subaltern receives pay and allowances amounting to $320 l$. a year if unmarried, or $394 l$. if married, and is able to look forward to generous increments on promotion and to an adequate pension. It will be a breach of trust if, under these conditions, the Army Council does not propose far-reaching reforms as regards standards of education and training for the commissioned ranks. 
There is no reason why a standard of professional training at least equal to that required by other professions, such as medicine and engineering, should not be required by the Army, and the only imaginable obstacle to this reform are the protests of old Regular officers, who think that the system which produced them must be the best possible. That particular obstacle has been overcome more than once in the history of the British Army, and it should not deter Mr. Churchill if he will devote to this reform some of the energy which he expends so generously on more forlorn objects.

To pass from destructive to constructive criticism, we would urge that the standard of education represented by three years' study at a University should, as a general rule, be demanded of all Army officers; in other words, that the raw material for the commissioned ranks should be University graduates rather than publicschool boys. The military colleges at Woolwich and Sandhurst should no longer be used as seminaries for the elementary education of adolescents.

A great economy of public money would be effected by this simple reform. According to the Estimates for 1919-20, Sandhurst for 700 cadets will cost a gross amount of 195,350l., being $279 l$. Is. $5 d$. per cadet per annum, while Woolwich for 280 cadets will cost $86,850 l$., or $3 \mathrm{rol}$. $3 s .7 d$. per cadet per annum. It is "pure" education which these young men chiefly require; they should obtain it in the Universities, which can offer a wide variety of curriculum and abundant facilities for social intercourse with all types of student. The University contingents of the Officers Training Corps are admirably adapted for providing elementary military training, which could be supplemented within the Army before and after the student takes his commission. Incidentally, the Army would be able to select for its commissioned ranks mature men possessing a livelier sense of vocation than can be expected from schoolboys.

If the quality of the raw material were improved in the way suggested, there should be no ground for nervousness as to the finished product. Methods could easily be devised of advancing and specialising the military training of these young University graduates. In time a corps d'élite would be formed able to study the art of war in all its aspects and to apply new scientific ideas and discoveries to national defence.

$$
\text { NO. } 2632 \text {, VOL. IO5] }
$$

\section{Woods and Water Supply.}

Forests, Woods, and Trees in Relation to Hygiene. By Prof: Augustine Henry. (The Chadwick Library.) Pp. xii +314 . (London: Constable and Co., Ltd., I9I9.) Price $18 s$. net.

DROF. HENRY writes of forests, woods, and trees with an enthusiastic appreciation of the beneficent part they play in the economy of Nature and in the service of man. He has devoted great energy to the study of his subject, and collected data of much value which will prove very useful to those engaged in projects of afforestation in this country. The importance of the subject is, we believe, fully realised by the Government, and Prof. Henry adduces so many instances of local authorities which have begun to move in the matter that we may hope to see the restoration of the woods on waste lands making steady progress year by year.

The book before us is an amplification of the Chadwick Lectures delivered by Prof. Henry at the Royal Society of Arts in 1917, and the author no doubt looks upon it in large measure as propaganda in the cause of tree-planting on a national scale. The first three chapters, however, deal with matters of profound scientific importancethe influence of forests on climate, the sanitary influence of forests, and forests as sites for sanatoria. These are difficult matters, as Prof. Henry fully realises, and some of them have agitated students of physical geography for generations. The difficulty of the question of the influence of forests on climate arises in great measure from the fact that climate has a great influence on forests, so that in wooded areas the interplay of cause and effect becomes extremely complicated.

Prof. Henry has read up the subject widely, but the nature of his book makes it impossible for him to focus the results sharply enough. $\mathrm{He}$ abundantly justifies the thesis that an increase of forest growth is of national importance for improving the hygiene and the economic condition of this country; but he scarcely attempts a scientific demonstration of the mechanism by which the beneficial effects are produced. He does, indeed, direct the attention of his readers to many recent investigations which it is most useful to have brought together, and for this guidance the student who wishes to go farther should be sincerely grateful.

We cannot, however, accept the results of some of the series of observations refurred to without a more critical discussion of the methods employed and the data recorded in different piirs of the world. In particular we agree with Prot. Henry in his opinion that the effect of afforestation in 